\title{
Badanie frakcjonowania lekkich materiałów obniżających gęstość jako wstępnego parametru podczas projektowania receptury zaczynu lekkiego
}

\section{The tests of the fractionation of lightweight additives that reduce density as a preliminary parameter when designing a lightweight cement slurry}

\author{
Marcin Kremieniewski, Miłosz Kędzierski \\ Instytut Nafty i Gazu - Państwowy Instytut Badawczy
}

\begin{abstract}
STRESZCZENIE: Lekkie domieszki obniżające gęstość zaczynów są stosowane w recepturach przeznaczanych do cementowania otworów wiertniczych w rejonie występowania skał słabo zwięzłych, sypkich, niekiedy do rekonstrukcji odwiertu bądź w razie konieczności podniesienia zaczynu na duże wysokości w przestrzeni pierścieniowej (głębokie otwory). Zastosowanie wypełniaczy lekkich pozwala w szybki i skuteczny sposób obniżyć gęstość projektowanego zaczynu, jednak ciągle pojawia się problem z nadmiernym frakcjonowaniem zaczynu zawierającego takie materiały. Rozdzielanie się poszczególnych frakcji zaczynu skutkuje uzyskaniem niejednorodnej struktury płaszcza cementowego, nieskutecznym zacementowaniem oraz możliwością powstawania dróg migracji i ekshalacji gazu. W celu wyeliminowania tego niekorzystnego zjawiska stosuje się różnego rodzaju środki (np. polimerowe), które poprzez zwiększenie lepkości cieczy zarobowej oraz granicy płynięcia projektowanego zaczynu pozwalają utrzymać lekką frakcję w całej objętości cieczy. Jednak obecność polimerów może niekiedy wpływać niekorzystnie na pozostałe parametry zaczynu, które decydują o efektywności uszczelnienia otworu. Dlatego też bardzo istotny jest odpowiedni dobór jakościowy i ilościowy planowanych do zastosowania dodatków i domieszek. Jednym z ważnych badań podczas projektowania receptury zaczynu lekkiego jest określenie wstępnego parametru, czyli frakcjonowania lekkich domieszek obniżających gęstość zaczynu. Tego rodzaju testy zostały omówione w niniejszej publikacji. W artykule przedstawiono metodykę badań frakcjonowania wybranych wypełniaczy lekkich oraz zaprezentowano uzyskane wyniki. W trakcie realizacji prac skoncentrowano się głównie na określeniu szybkości frakcjonowania lekkich materiałów wypełniających, ponieważ to właśnie te dodatki wykazują największy wpływ na stabilność sedymentacyjną opracowywanego zaczynu cementowego. Wykonane zostały badania frakcjonowania wypełniaczy lekkich w jednostce czasu, na podstawie czego możliwe było określenie przydatności danego dodatku lekkiego do sporządzenia zaczynu lekkiego o odpowiedniej stabilności sedymentacyjnej.
\end{abstract}

Słowa kluczowe: zaczyn cementowy, zaczyn lekki, frakcjonowanie, mikrosfery, wypełniacze lekkie.

ABSTRACT: Light additives reducing cement slurry density are used in recipes intended for cementing boreholes in the area of weak, loose rocks, sometimes for bore reconstruction or when it is necessary to raise the slurry to high heights in the annular space (deep holes). The use of lightweight additives makes it possible to quickly and effectively reduce the density of the designed cement slurry but there is still a problem with the excessive fractionation of the cement slurry containing such materials. Separation of individual fractions results in obtaining a heterogeneous structure of the cement sheath, ineffective cementing and the possibility of formation of migration and gas exhalation paths. In order to eliminate this unfavorable phenomenon, various agents (e.g. polymeric) are used which, by increasing the viscosity of the mixing fluid and the flow limit of the proposed cement slurry, allow keeping the light fraction in the entire volume of the liquid. However, the presence of polymers can sometimes adversely affect other grout parameters that determine the effectiveness of sealing the borehole. Therefore, it is very important to choose the right qualitative and quantitative additions and additives planned for use. One of the important research factors when designing a lightweight cement slurry recipe is to determine the initial parameter, i.e. the fractionation of light admixtures that reduce the leaven density. These types of tests are discussed in this publication. The article presents the methodology of fractionation testing of selected light fillers and the results obtained. During the implementation of the work, the focus was mainly on determining the fractionation rate of lightweight filler materials because these additives are the ones that show the greatest effect on the sedimentation stability of the cement slurry being developed. Light fractionation tests were performed per unit of time, based on which it was possible to determine the suitability of a given light additive in order to prepare a light cement slurry with appropriate sedimentation stability.

Key words: cement slurry, lightweight cement slurry, fractionation, microspheres, light additives.

Autor do korespondencji: M. Kremieniewski, e-mail: marcin.kremieniewski@inig.pl

Artykuł nadesłano do Redakcji 30.08.2019 r. Zatwierdzono do druku 03.12.2019 r. 


\section{Wprowadzenie}

Przeprowadzony odpowiednio, zgodnie z projektem, zabieg cementowania kolumny rur okładzinowych w otworze wiertniczym jest istotnym elementem wykonania otworu. Zagadnienie prawidłowego zarurowania i cementowania kolumny eksploatacyjnej nabiera szczególnego znaczenia podczas uszczelniania otworów wierconych w strefach chłonnych (Nelson et al., 1990; Kremieniewski, 2019c). Technologia cementowania otworów wiertniczych na złożach o niskim ciśnieniu złożowym nie ulega znacznej zmianie, ale pojawiają się różnice w rodzaju stosowanych zaczynów cementowych (Kremieniewski i Stryczek, 2019). Cementowanie otworów w warunkach niskich ciśnień złożowych w strefach chłonnych przysparza zazwyczaj wielu problemów, dlatego też znaczne nakłady pracy poświęca się w placówkach badawczych i przemysłowych na wprowadzenie innowacyjnych materiałów uszczelniających (Jordan et al., 2018; Kremieniewski, 2018). Rurowanie i cementowanie otworów wiertniczych na złożach o niskim ciśnieniu stanowi jeden z poważniejszych i trudnych do rozwiązania problemów ze względu na możliwość pojawienia się komplikacji. Związane są one z występowaniem strefy anomalnie niskiego ciśnienia złożowego, w której może nastąpić przechodzenie zaczynu cementowego przez wypełniany profil geologiczny i ucieczka cementu, a w konsekwencji brak uszczelnienia danego interwału (Stryczek et al., 2005; Kremieniewski et al., 2017). Wstępne wyeliminowanie możliwości powstawania tego rodzaju komplikacji polega na zastosowaniu na etapie wiercenia otworu płuczki o odpowiednio dobieranych parametrach. Niestety również podczas cementowania otworu w strefie anomalnie niskiego ciśnienia złożowego czy stref słabo zwięzłych i sypkich występują problemy z odpowiednim doborem parametrów zaczynu. Do uszczelniania kolumn rur okładzinowych w tego rodzaju warunkach geologicznych należy stosować zaczyn o obniżonej gęstości. Zaczyn lekki powinien charakteryzować się stosunkowo niską wartością filtracji, odpowiednim czasem gęstnienia i odpowiednimi wartościami parametrów reologicznych (Wiśniowski et al., 2007; Stryczek et al., 2009; Kremieniewski, 2019a). Podczas sporządzania zaczynu lekkiego jego skład wzbogacany jest o dodatki lekkich frakcji. Są to różnego rodzaju wypełniacze, jak np. dodatki redukujące gęstość zaczynów cementowych. Najczęściej stosowanymi dodatkami w celu obniżenia gęstości zaczynu są wypełniacze zbudowane z cząsteczek o wiele lżejszych niż ziarna cementu. Do takich dodatków można zaliczyć: perlit, sproszkowany węgiel, gilsonit i ceramiczną bądź szklaną mikrosferę.

Perlit to rodzaj szkła wulkanicznego (rys. 1), które zwiększa swoją objętość na skutek podgrzania do wysokiej temperatury. Taka ekspansja cząsteczek szkła wulkanicznego powoduje wzrost objętości skutkujący jednoczesnym obniżeniem gęstości otrzymanego produktu. Gęstość perlitu osiąga wówczas $1120 \mathrm{~kg} / \mathrm{m}^{3}$. Struktura perlitu zawiera zarówno pory zamknięte, jak i otwarte, które pod wpływem wzrostu ciśnienia hydrostatycznego wypełniają się wodą (otwarte) lub kruszą się (zamknięte) pod naporem cieczy. Dlatego też gęstość zaczynu z perlitem zmierzona na powierzchni będzie zawsze niższa niż jego gęstość w warunkach otworowych (Kremieniewski, 2017b).

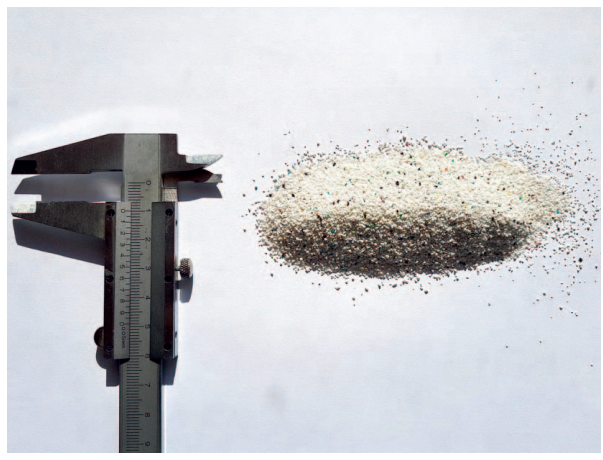

Rys. 1. Perlit

Fig. 1. Perlite

Gilsonit to materiał, który odkryto w złożach Kolorado w stanie Utah. Występuje naturalnie jako minerał asfaltowy (rys. 2). Gęstość gilsonitu wynosi około $1070 \mathrm{~kg} / \mathrm{m}^{3}$ i zastosowanie go pozwala na sporządzenie zaczynu o niskiej gęstości i wysokiej wytrzymałości na ściskanie. Gilsonit występuje w postaci czarnych nieregularnych granulek o różnym uziarnieniu, do $6 \mathrm{~mm}$. Jedynym ograniczeniem w stosowaniu gilsonitu w technologii zaczynów cementowych jest jego temperatura topnienia, wynosząca $196^{\circ} \mathrm{C}$, oraz mięknienie gilsonitu, które następuje już w $116^{\circ} \mathrm{C}$ (Stryczek et al., 2014; Kremieniewski, 2017a)

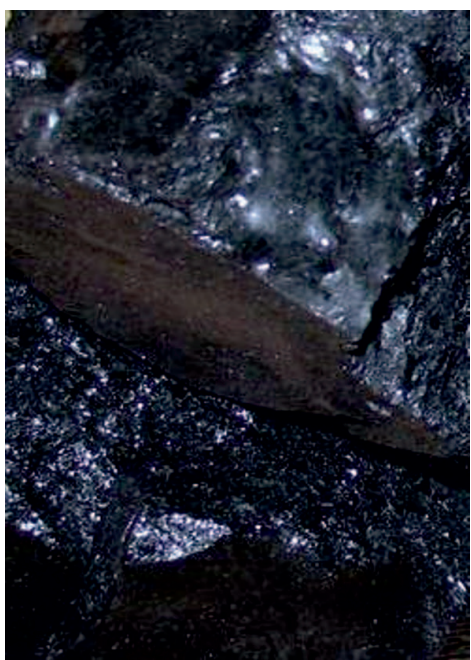

Rys. 2. Gilsonit

Fig. 2. Gilsonite

Sproszkowany węgiel to materiał stosowany w technologii zaczynów cementowych o podobnej funkcji jak gilsonit. Jego gęstość nasypowa wynosi $1300 \mathrm{~kg} / \mathrm{m}^{3}$. Podobnie jak gilsonit, również węgiel (rys. 3) może być wykorzystany do obniżania gęstości zaczynu. Węgiel w przeciwieństwie do gilsonitu charakteryzuje się wysoką temperaturą topnienia $\left(3550^{\circ} \mathrm{C}\right)$, co daje 
możliwość stosowania pyłu węglowego do sporządzania zaczynów cementowych przeznaczonych do warunków termalnych.

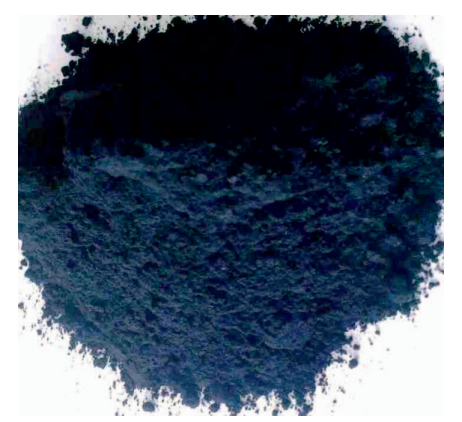

Rys. 3. Sproszkowany węgiel

Fig. 3. Powdered coal

Mikrosfery to proszek w postaci drobin wypełnionych gazem (rys. 4). Gęstość nasypowa mikrosfer zawiera się w przedziale od 50 do $70 \mathrm{~kg} / \mathrm{m}^{3}$. Wyróżnić można mikrosfery ceramiczne oraz mikrosfery szklane. Jednym z większych ograniczeń stosowania mikrosfer ceramicznych jest ciśnienie hydrostatyczne w otworze, co uniemożliwia ich użycie w zaczynach przeznaczonych do uszczelniania głębokich otworów. Uziarnienie mikrosfer zawiera się w przedziale od 20 do 200 mikrometrów. Mikrosfery ceramiczne wytrzymują ciśnienia do około $30 \mathrm{MPa}$, jednak występują również odmiany mikrosfer szklanych, które posiadają odporność na ciśnienia dochodzące do $130 \mathrm{MPa}$. Gęstość rzeczywista mikrosfer szklanych wynosi od 29 do $63 \mathrm{~kg} / \mathrm{m}^{3}$, a wielkości cząstek tego rodzaju mikrosfer wynoszą od 1 do 100 mikrometrów. Mikrosfery ceramiczne są pochodnymi pyłów piecowych, a w ich skład wchodzą gazy $\mathrm{CO}_{2}$ i $\mathrm{N}_{2}$. Ceramiczne mikrosfery są nieco cięższe niż szklane (gęstość $70 \mathrm{~kg} / \mathrm{m}^{3}$ ), jednak ze względu na niższą cenę w porównaniu do mikrosfer szklanych są częściej stosowane (Kremieniewski, 2017a).

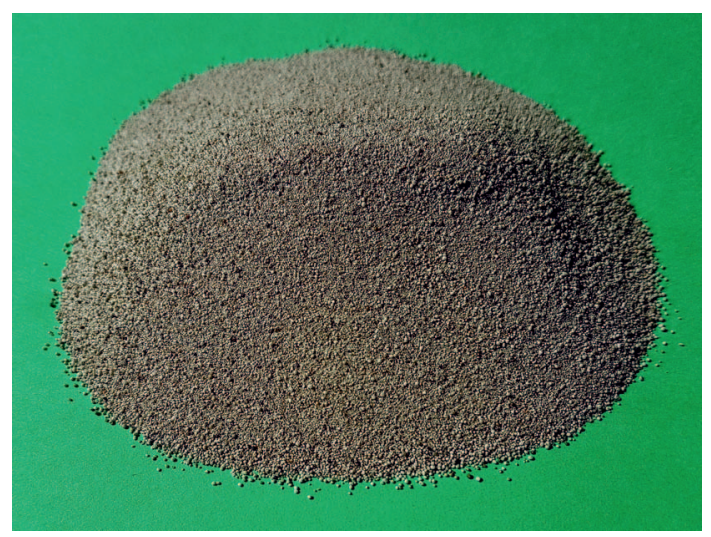

Rys. 4. Próbka mikrosfery ceramicznej

Fig. 4. Ceramic microsphere sample

Wprowadzenie lekkich wypełniaczy w strukturę płynnego zaczynu cementowego jest najlepszym sposobem na uzyskanie wymaganej niskiej gęstości zaczynu. Jednakże stosowanie tego rodzaju środków w celu obniżenia gęstości może powodować unoszenie się lekkich cząstek (Peng i Jacobsen, 2013; Kremieniewski, 2019b), dlatego też korzystne jest przeprowadzenie wstępnych badań frakcjonowania domieszek lekkich i na podstawie analizy uzyskanych wyników zastosowanie najlepszego dodatku, co zostało omówione w dalszej części niniejszej publikacji.

\section{Przebieg prac badawczych}

Badania frakcjonowania lekkich domieszek obniżających gęstość, jako wstępnego parametru przed zaprojektowaniem receptury zaczynu lekkiego, wykonane zostały w Laboratorium Zaczynów Uszczelniających INiG - PIB. Lekkie dodatki w recepturze zaczynu ulegają frakcjonowaniu, jednak jest to mało widoczne ze względu na brak przejrzystości zaczynu oraz jego znaczną lepkość. Dlatego też badania doboru środków oraz analizę frakcjonowania przeprowadzono według następującej metodyki. W wodzie $\left(250 \mathrm{~cm}^{3}\right)$ zmieszano ustaloną $(0,5 \% ; 1 \%$; $2,5 \% ; 5 \% ; 10 \%)$ ilość wytypowanego wypełniacza lekkiego. Po wymieszaniu w elektrycznym mikserze cementowym z określoną prędkością obrotową (2000 obr/min) mieszaninę przelano do cylindra miarowego o pojemności $250 \mathrm{~cm}^{3}$. Następnie po ustalonym czasie (po 2,5 min; $5 \mathrm{~min}$; 7,5 min; $10 \mathrm{~min} ; 15 \mathrm{~min}$; 20 min oraz $30 \mathrm{~min}$ ) odczytywano ilość dodatku przemieszczającego się w górną część cylindra. W celu uzyskania kontrastu woda została zabarwiona barwnikiem w ilości $0,05 \%$. Na podstawie otrzymanych wyników możliwe było określenie stabilności danego środka w cieczy niskolepkiej, jaką jest woda.

Do badań wytypowano grupę dodatków obniżających gęstość zaczynów cementowych. Badania frakcjonowania przeprowadzono dla następujących lekkich wypełniaczy do zaczynów:

- mikrosfera GK;

- mikrosfera CK;

- perlit PF;

- mikrosfera HG5K.

Następnie wykonane zostały badania, których celem było określenie frakcjonowania (rozdzielania na warstwy w zależności od gęstości) środków służących do obniżania gęstości zaczynów cementowych.

\section{Mikrosfera GK}

Pierwszym poddanym badaniom dodatkiem była mikrosfera GK. W tabeli 1 zestawiono wyniki badań frakcjonowania dodatku mikrosfery w zależności od stężenia i w zależności od czasu. Na podstawie badań stwierdzono znaczne frakcjonowanie (unoszenie się ku górze) mikrosfery już w początkowym okresie. Bezpośrednio po przelaniu cieczy z miksera do cylindrów widoczne było rozwarstwienie w zakresie 
Tabela 1. Frakcjonowanie różnych stężeń lekkiego dodatku w zależności od czasu

Table 1. Fractionation of different concentrations of light additive depending on time

\begin{tabular}{|c|c|c|c|c|c|c|}
\hline \multirow{5}{*}{$\begin{array}{c}\mathrm{Nr} \\
\text { rysunku }\end{array}$} & \multirow{5}{*}{$\begin{array}{c}\text { Czas } \\
\text { [minuty] }\end{array}$} & \multicolumn{5}{|c|}{ Ilość mikrosfery w górnej części $\left[\mathrm{cm}^{3}\right]$} \\
\hline & & \multicolumn{5}{|c|}{$\begin{array}{c}\text { Numer próbki } \\
\text { (na rys. licząc od lewej strony) }\end{array}$} \\
\hline & & 1 & 2 & 3 & 4 & 5 \\
\hline & & \multicolumn{5}{|c|}{ Ilość dodatku [\%] } \\
\hline & & 0,5 & 1,0 & 2,5 & 5,0 & 10 \\
\hline 6 & 0 & 4 & 8 & 16 & 32 & 56 \\
\hline 7 & 2,5 & 6 & 8 & 18 & 34 & 64 \\
\hline & 30,0 & 6 & 8 & 18 & 34 & 64 \\
\hline
\end{tabular}

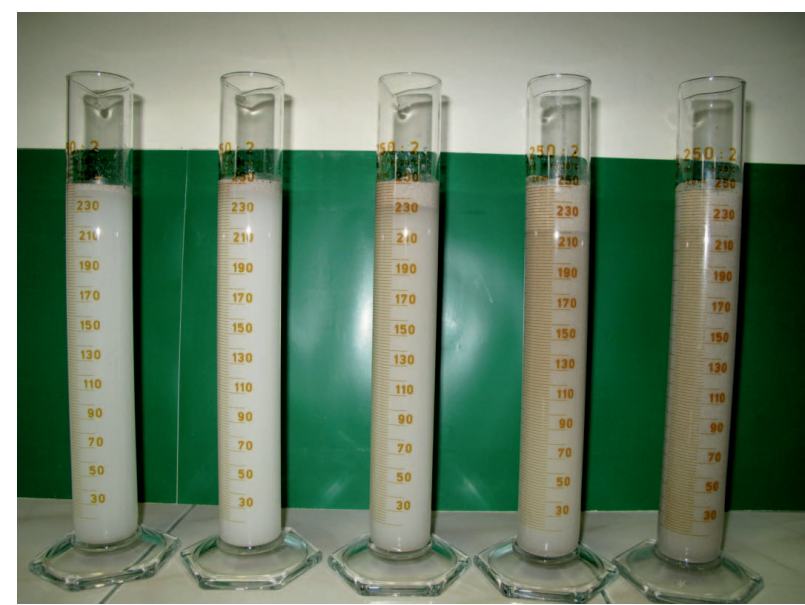

Rys. 6. Ilość frakcjonującej mikrosfery w zależności od czasu 0 minut

Fig. 6. The amount of fractionating microsphere depending on the time 0 minutes

od $4 \mathrm{~cm}^{3}$ do $56 \mathrm{~cm}^{3}$ (tab. 1 oraz rys. 5). Po czasie 2,5 minuty w górnej części cylindra obserwowano wydzieloną mikrosferę w ilości od $6 \mathrm{~cm}^{3}$ przy stężeniu $0,5 \%$ mikrosfery w wodzie do $64 \mathrm{~cm}^{3}$ dla stężenia 5\% mikrosfery w wodzie (tab. 1 oraz rys. 5). Takie ilości utrzymywały się do końca trwania pomiaru, czyli do odczytu po 30 minutach (zaznaczenie kolorem czerwonym w tab. 1). Graficzne porównanie frakcjonowania w zależności od czasu i stężenia użytych dodatków przedstawiono na rysunkach 6 i 7 .

\section{Mikrosfera CK}

Drugim środkiem wytypowanym do obniżenia gęstości zaczynu cementowego była mikrosfera $\mathrm{CK}$. Na podstawie analizy uzyskanych wyników badań (tab. 2) również zaobserwowano frakcjonowanie od razu po przelaniu cieczy do cylindra. Mikrosfera CK wydzielała się w górnej części cylindra w zakresie od $4 \mathrm{~cm}^{3}$ przy stężeniu $0,5 \%$ do $48 \mathrm{~cm}^{3}$ przy stężeniu $5 \%$ (tab. 2 , rys. 8 ). Po czasie 2,5 minuty frakcjonowanie

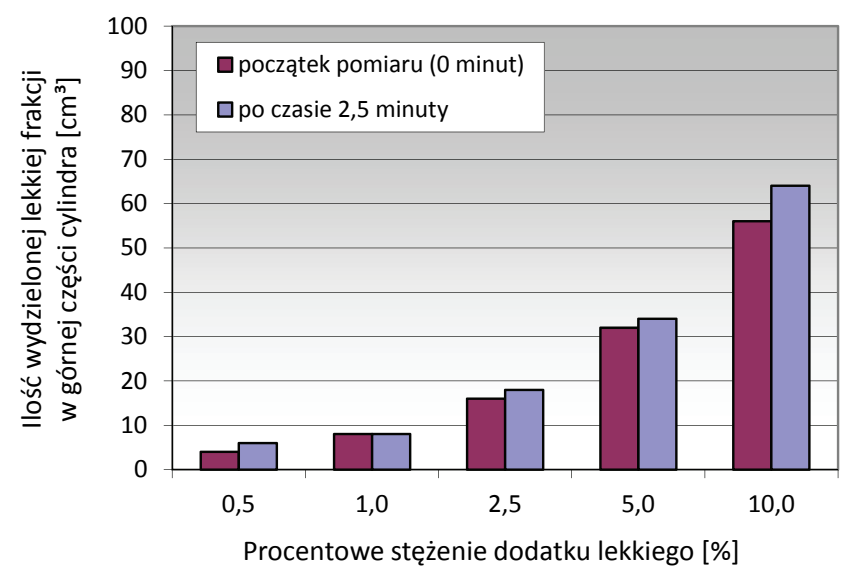

Rys. 5. Wydzielanie się dodatku lekkiego w górnej części cylindra Fig. 5. Release of a light additive at the top of the cylinder

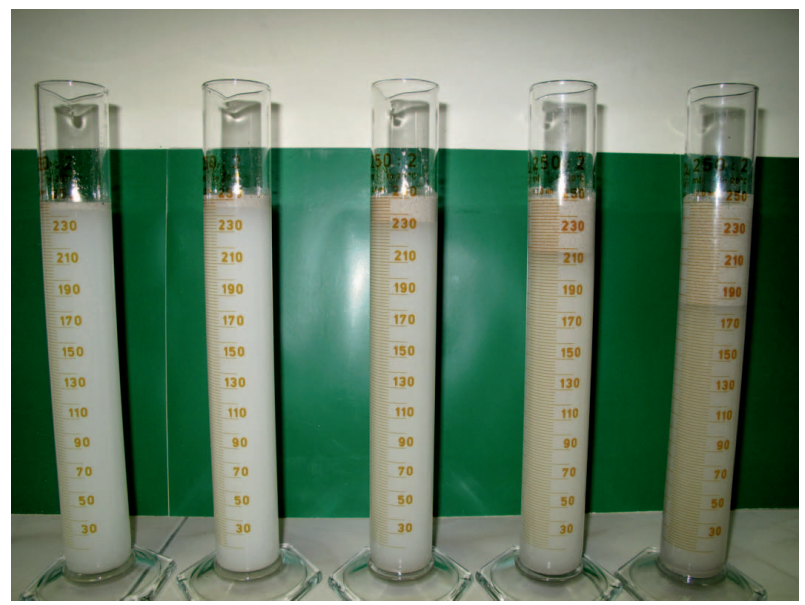

Rys. 7. Ilość frakcjonującej mikrosfery w zależności od czasu 2,5 minuty

Fig. 7. The amount of fractionating microsphere depending on the time 2.5 minutes

wynosiło od $6 \mathrm{~cm}^{3}$ dla stężenia $0,5 \%$ do $94 \mathrm{~cm}^{3}$ dla stężenia $10 \%$ (tab. 2, rys. 8), które to wartości były znacznie wyższe niż podczas badania mikrosfery GK. Graficzne porównanie frakcjonującej mikrosfery CK przedstawiają rysunki 9 i 10.

\section{Perlit PF}

Trzecim dodatkiem, który poddano badaniom, był perlit PF. Z uwagi na niewielką porcję środka dostarczoną do badań, a jednocześnie ze względu na niską gęstość nasypową i związaną z tym znaczną ilość używaną do badań - testy wykonano dla stężeń $0,5 \%$; $1 \%$ oraz $5 \%$. Analizując uzyskane wyniki badań (tab. 3), zaobserwowano bardzo mocne frakcjonowanie od razu po przelaniu cieczy do cylindra. Lekka frakcja perlitu wydzielała się w zakresie od $8 \mathrm{~cm}^{3}$ przy stężeniu $0,5 \%$ do $70 \mathrm{~cm}^{3}$ przy stężeniu 5\% (tab. 3, rys. 11). Natomiast po czasie $2,5 \mathrm{mi}-$ nuty frakcjonowanie wynosiło od $10 \mathrm{~cm}^{3}$ dla stężenia $0,5 \%$ do $94 \mathrm{~cm}^{3}$ dla stężenia $5 \%$ (tab. 3, rys. 11). Graficzne porównanie frakcjonującego perlitu PF przedstawiają rysunki 12 i 13. 
Tabela 2. Frakcjonowanie różnych stężeń lekkiego dodatku w zależności od czasu

Table 2. Fractionation of different concentrations of light additive depending on the time

\begin{tabular}{|c|c|c|c|c|c|c|}
\hline \multirow{2}{*}{$\begin{array}{c}\text { Nr } \\
\text { Nysunku }\end{array}$} & \multirow{5}{*}{$\begin{array}{c}\text { Czas } \\
\text { [minuty] }\end{array}$} & \multicolumn{5}{|c|}{$\begin{array}{c}\text { Numer próbki } \\
\text { (na rys. licząc od lewej strony) }\end{array}$} \\
\cline { 3 - 7 } & & $\mathbf{1}$ & $\mathbf{2}$ & $\mathbf{3}$ & $\mathbf{4}$ & $\mathbf{5}$ \\
\cline { 3 - 7 } & & \multicolumn{5}{|c|}{ Ilość dodatku [\%] } \\
\cline { 3 - 7 } & & $\mathbf{0 , 5}$ & $\mathbf{1 , 0}$ & $\mathbf{2 , 5}$ & $\mathbf{5 , 0}$ & $\mathbf{1 0}$ \\
\hline \hline 9 & 0 & 4 & 8 & 22 & 48 & 0 \\
\hline 10 & 2,5 & 6 & 10 & 24 & 48 & 94 \\
\hline & 30,0 & 6 & 10 & 24 & 48 & 94 \\
\hline
\end{tabular}

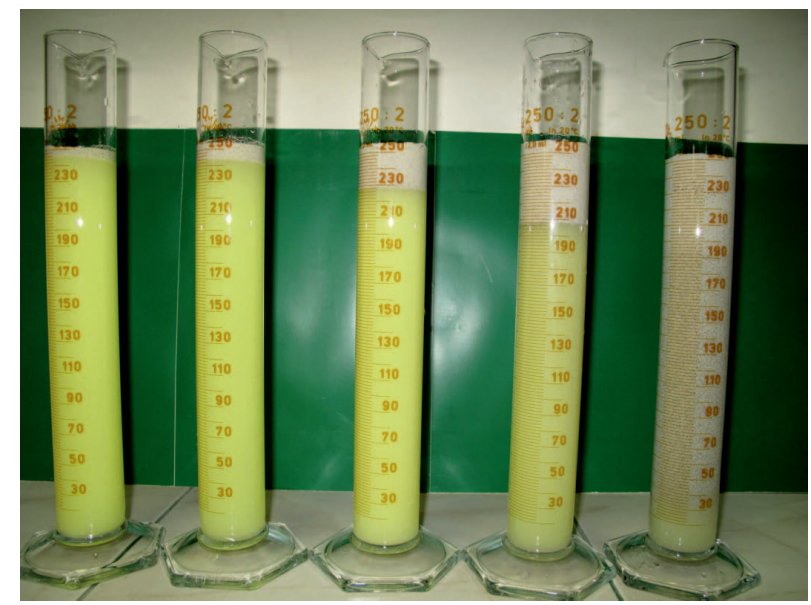

Rys. 9. Ilość frakcjonującej mikrosfery w zależności od czasu 0 minut

Fig. 9. The amount of fractionating microsphere depending on the time 0 minutes

Tabela 3. Frakcjonowanie różnych stężeń lekkiego dodatku w zależności od czasu

Table 3. Fractionation of different concentrations of light additive depending on the time

\begin{tabular}{|c|c|c|c|c|c|c|}
\hline \multirow{5}{*}{$\begin{array}{c}\mathrm{Nr} \\
\text { rysunku }\end{array}$} & \multirow{5}{*}{$\begin{array}{c}\text { Czas } \\
{[\text { minuty] }}\end{array}$} & \multirow{2}{*}{\multicolumn{5}{|c|}{$\begin{array}{c}\text { Ilość perlitu w górnej części }\left[\mathrm{cm}^{3}\right] \\
\text { Numer próbki } \\
\text { (na rys. licząc od lewej strony) }\end{array}$}} \\
\hline & & & & & & \\
\hline & & 1 & 2 & 3 & 4 & 5 \\
\hline & & \multicolumn{5}{|c|}{ Ilość dodatku [\%] } \\
\hline & & 0,5 & 1,0 & 2,5 & 5,0 & 10 \\
\hline 12 & 0 & 8 & 14 & & 70 & \\
\hline \multirow[t]{2}{*}{13} & 2,5 & 10 & 16 & & 94 & \\
\hline & 30,0 & 10 & 16 & & 98 & \\
\hline
\end{tabular}

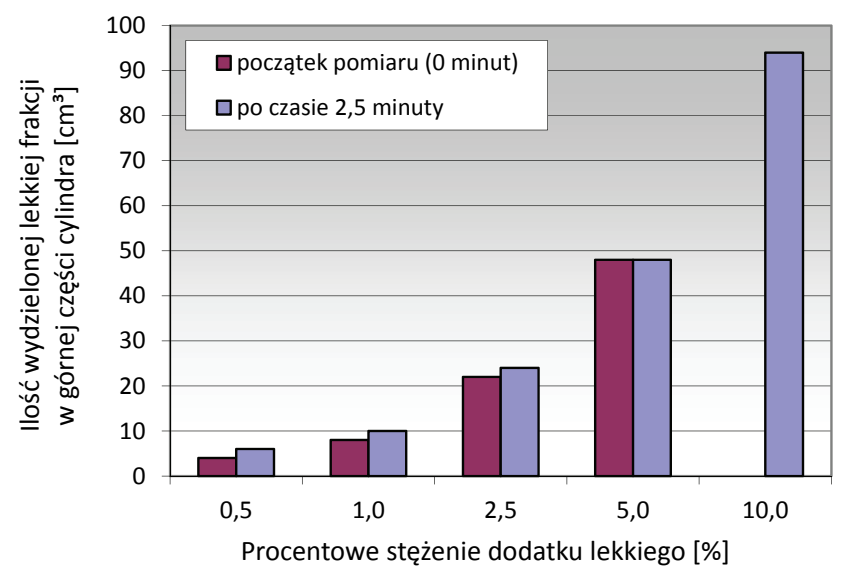

Rys. 8. Wydzielanie się dodatku lekkiego w górnej części cylindra Fig. 8. Release of a light additive at the top of the cylinder

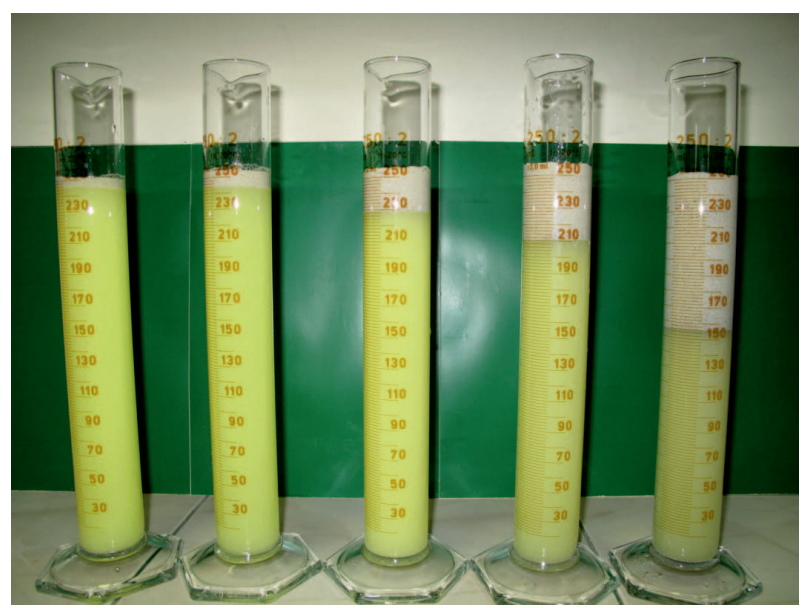

Rys. 10. Ilość frakcjonującej mikrosfery w zależności od czasu 2,5 minuty

Fig. 10. The amount of fractionating microsphere depending on the time 2.5 minutes

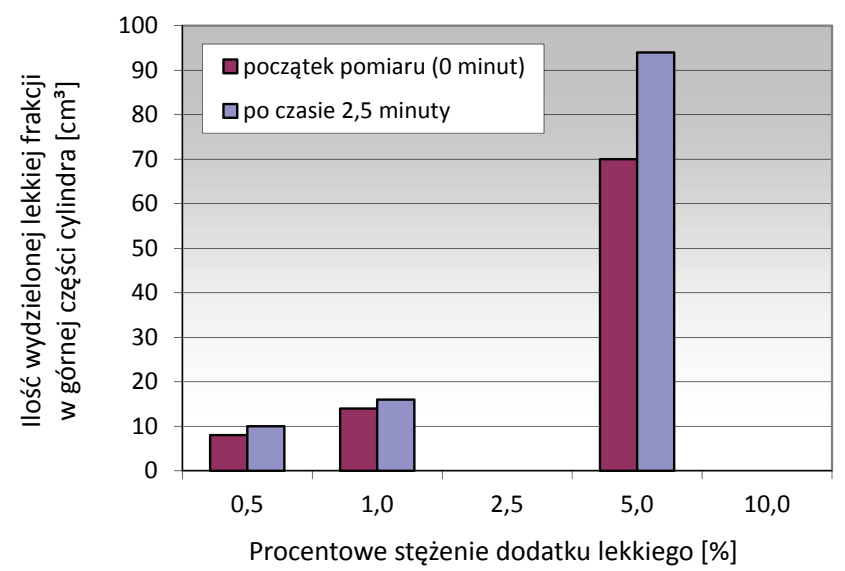

Rys. 11. Wydzielanie się dodatku lekkiego w górnej części cylindra Fig. 11. Release of a light additive at the top of the cylinder 


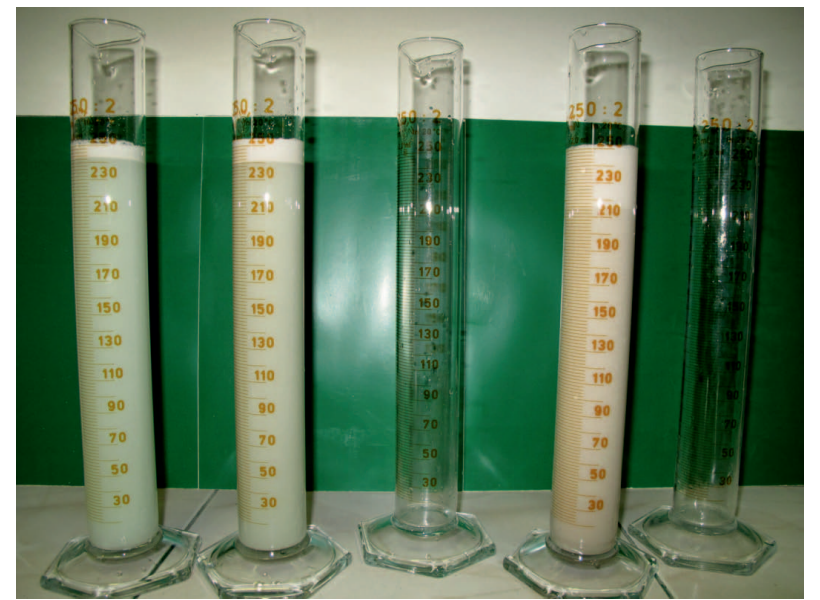

Rys. 12. Ilość frakcjonującego wypełniacza w zależności od czasu 0 minut

Fig. 12. Amount of fractionating additive depending on the time 0 minutes

\section{Mikrosfera HG5K}

Czwartym środkiem była mikrosfera HG5K. Badania dla tego wypełniacza zostały przeprowadzone również dla stężeń $0,5 \% ; 1 \%$ oraz $5 \%$. Analizując zestawione w tabeli 4 wyniki badań, stwierdzono słabszą tendencję do frakcjonowania niż w przypadku wcześniejszych środków. Dla mikrosfery szklanej HG5K w początkowym okresie (po przelaniu do cylindra miarowego) odnotowano bardzo małe frakcjonowanie - w zakresie od $4 \mathrm{~cm}^{3}$ przy stężeniu $0,5 \%$ do $8 \mathrm{~cm}^{3}$ przy stężeniu 5\% (tab. 4, rys. 14). Po czasie 2,5 minuty frakcjonowanie nieznacznie wzrosło i wynosiło od $6 \mathrm{~cm}^{3}$ dla stężenia $0,5 \%$ do $24 \mathrm{~cm}^{3}$ dla stężenia $5 \%$ (tab. 4 , rys. 14). Dopiero po czasie od 5 do 10 minut następował mocniejszy wzrost intensywności wydzielania się mikrosfery szklanej w górnej części cylindra. Maksymalną wartość frakcjonowania odnotowano

Tabela 4. Frakcjonowanie różnych stężeń lekkiego dodatku w zależności od czasu

Table 4. Fractionation of different concentrations of light additive depending on the time

\begin{tabular}{|c|c|c|c|c|c|c|}
\hline \multirow{5}{*}{$\begin{array}{c}\mathrm{Nr} \\
\text { rysunku }\end{array}$} & \multirow{5}{*}{$\begin{array}{c}\text { Czas } \\
\text { [minuty] }\end{array}$} & \multirow{2}{*}{\multicolumn{5}{|c|}{$\begin{array}{c}\text { Ilość mikrosfery w górnej części }\left[\mathrm{cm}^{3}\right] \\
\text { Numer próbki } \\
\text { (na rys. licząc od lewej strony) }\end{array}$}} \\
\hline & & & & & & \\
\hline & & 1 & 2 & 3 & 4 & 5 \\
\hline & & \multicolumn{5}{|c|}{ Ilość dodatku [\%] } \\
\hline & & 0,5 & 1,0 & 2,5 & 5,0 & 10 \\
\hline 15 & 0 & 4 & 4 & & 8 & \\
\hline 16 & 2,5 & 6 & 8 & & 24 & \\
\hline 17 & 5,0 & 6 & 12 & & 36 & \\
\hline 18 & 7,5 & 6 & 12 & & 44 & \\
\hline \multirow[t]{2}{*}{19} & 10,0 & 8 & 12 & & 50 & \\
\hline & 30,0 & 8 & 12 & & 52 & \\
\hline
\end{tabular}

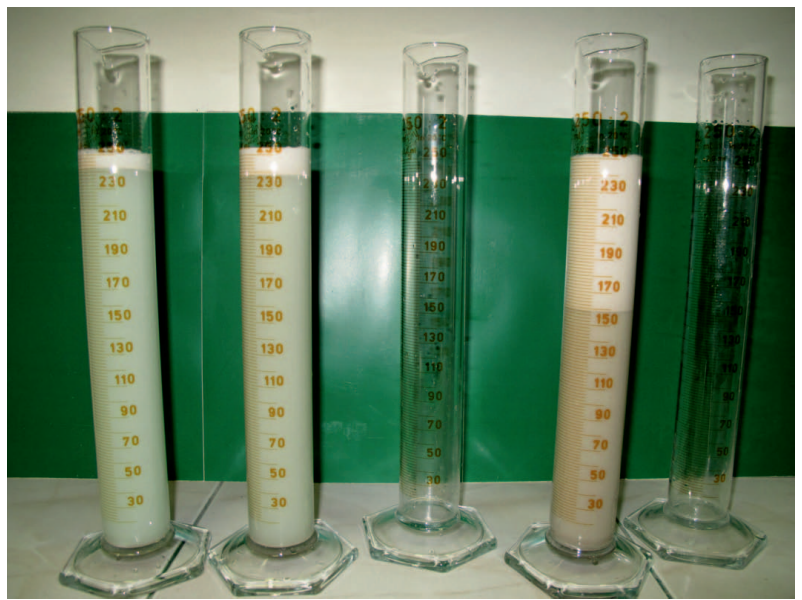

Rys. 13. Ilość frakcjonującego wypełniacza w zależności od czasu 2,5 minuty

Fig. 13. Amount of fractionating additive depending on the time 2.5 minutes

po 10 minutach pomiaru i wynosiła ona od $8 \mathrm{~cm}^{3}$ dla stężenia $0,5 \%$ do $50 \mathrm{~cm}^{3}$ dla stężenia $5 \%$ (tab. 4 , rys. 14). Graficzne porównanie frakcjonującej mikrosfery szklanej przedstawiają rysunki od 15 do 19.

Analizując uzyskane wyniki badań, stwierdzono najmocniejsze frakcjonowanie perlitu PF oraz mikrosfery CK. Dodatki te różnią się wymiarami ziaren. Perlit PF charakteryzuje się znacznie drobniejszym uziarnieniem oraz posiada niższą wartość ciężaru nasypowego, co powoduje, że frakcjonowanie perlitu jest intensywniejsze - uzyskano $94 \mathrm{~cm}^{3}$ po czasie $2,5 \mathrm{mi}-$ nuty przy koncentracji 5\% tego dodatku. Mocno frakcjonująca mikrosfera CK po tym samym czasie wydzieliła się w ilości $48 \mathrm{~cm}^{3}$ w górnej części cylindra zawierającego tę samą 5-procentową koncentrację dodatku. $\mathrm{Z}$ kolei porównując tę samą koncentrację (5\%) mikrosfery GK w tych samych warunkach

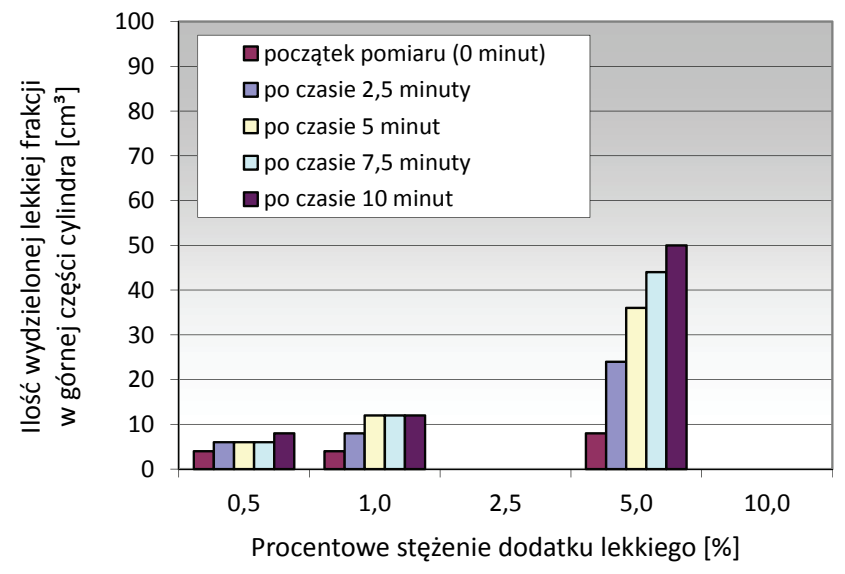

Rys. 14. Wydzielanie się dodatku lekkiego w górnej części cylindra

Fig. 14. Release of a light additive at the top of the cylinder 


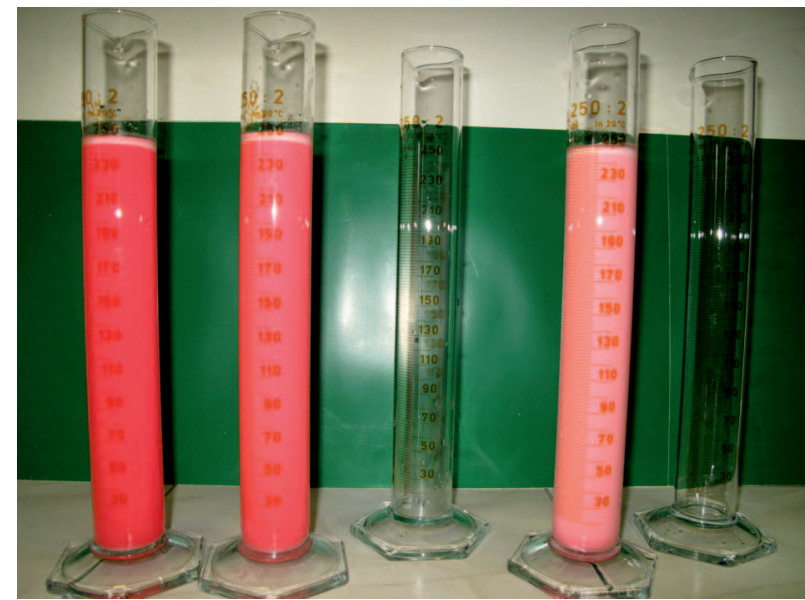

Rys. 15. Ilość frakcjonującej mikrosfery w zależności od czasu 0 minut

Fig. 15. The amount of fractionating microsphere depending on the time 0 minutes

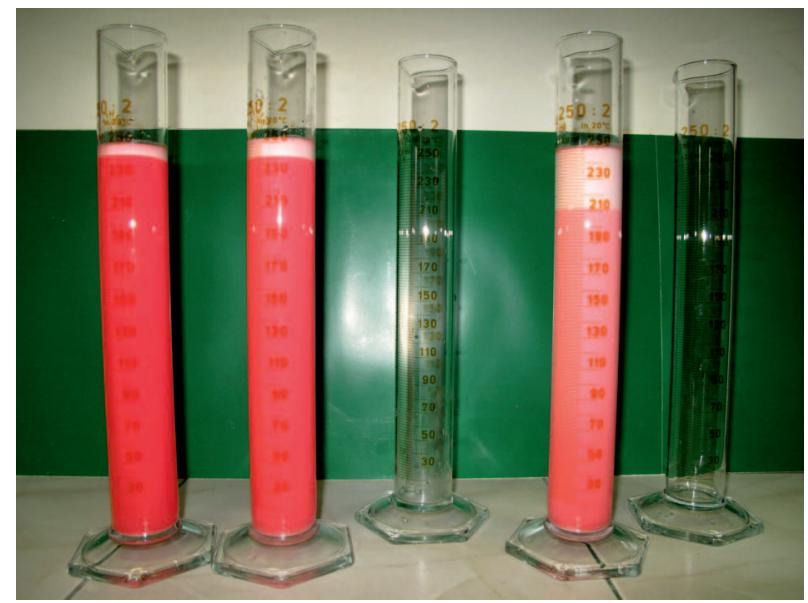

Rys. 17. Ilość frakcjonującej mikrosfery w zależności od czasu 5 minut

Fig. 17. The amount of fractionating microsphere depending on the time 5 minutes

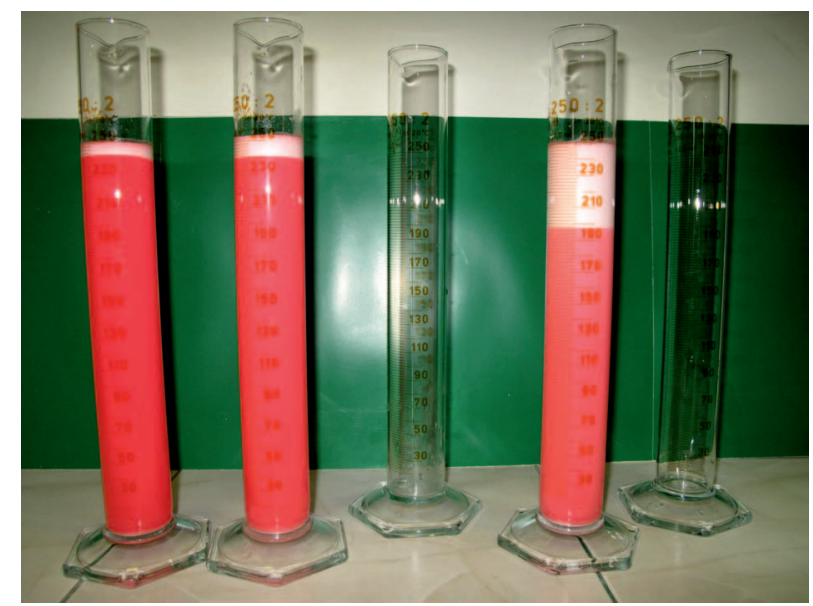

Rys. 19. Ilość frakcjonującej mikrosfery w zależności od czasu 10 minut

Fig. 19. The amount of fractionating microsphere depending on the time 10 minutes

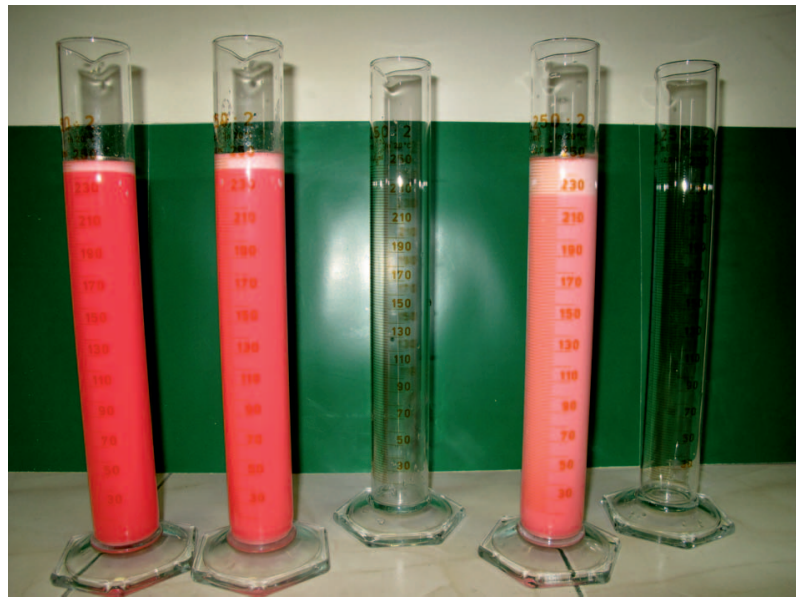

Rys. 16. Ilość frakcjonującej mikrosfery w zależności od czasu 2,5 minuty

Fig. 16. The amount of fractionating microsphere depending on the time 2.5 minutes

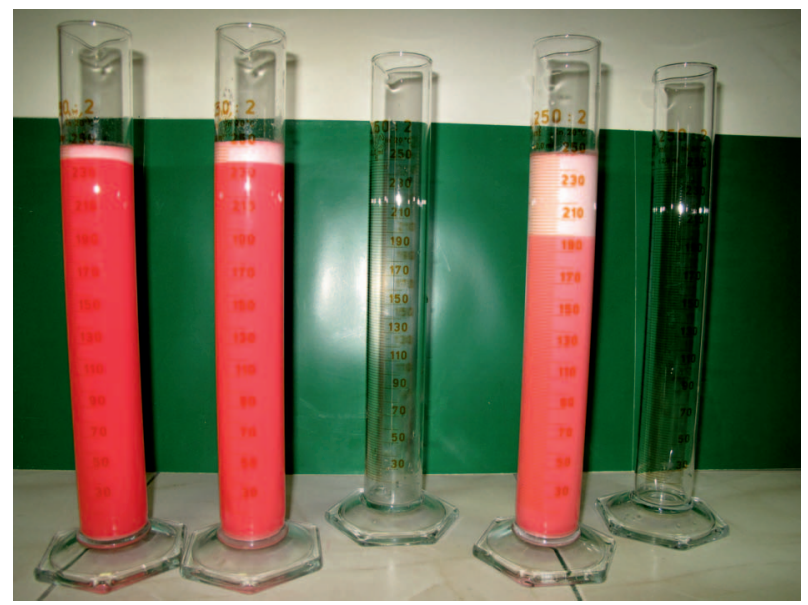

Rys. 18. Ilość frakcjonującej mikrosfery w zależności od czasu 7,5 minuty

Fig. 18. The amount of fractionating microsphere depending on the time 7.5 minutes

pomiaru (2,5 minuty), uzyskano frakcjonowanie wynoszące $34 \mathrm{~cm}^{3}$. Jednak ze wszystkich poddanych badaniom wypełniaczy lekkich najlepsze właściwości wykazywała mikrosfera HG5K, która wydzielała się bardzo powoli z niskolepkiej cieczy wzorcowej, jaką była woda. Porównując te same parametry pomiaru, po czasie 2,5 minuty przy koncentracji mikrosfery HG5K wynoszącej 5\% otrzymano frakcjonowanie w najniższej z badanych objętości, wynoszącej $24 \mathrm{~cm}^{3}$. Następnie wartość ta powoli wzrastała do $50 \mathrm{~cm}^{3}$ po $10 \mathrm{mi}$ nutach pomiaru, uzyskując $52 \mathrm{~cm}^{3} \mathrm{w}$ końcowym punkcie pomiaru (rys. 20), który przypisano na 30 minut (zaznaczenie kolorem czerwonym w tab. 3 ). 


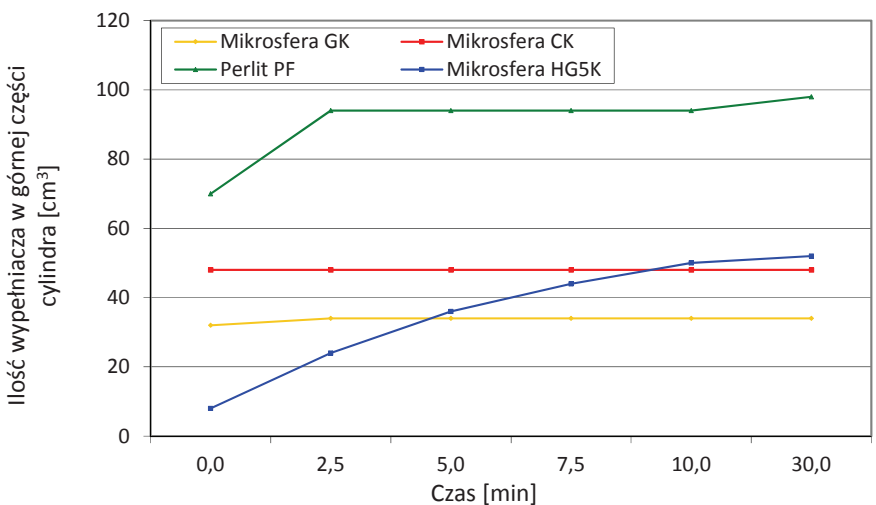

Rys. 20. Szybkość frakcjonowania wypełniaczy lekkich z wody. Stężenie 5\%

Fig. 20. The fractionation rate of light additives from water. $5 \%$ concentration

\section{Wnioski}

Na podstawie uzyskanych wyników badań frakcjonowania lekkich materiałów obniżających gęstość stwierdzono, że badanie frakcjonowania dodatków wypełniających - jako wstępnego parametru - może być stosowane podczas projektowania receptury zaczynu lekkiego. Dotychczas badania frakcjonowania były prowadzone tylko na gotowym zaczynie zawierającym dodatek lekkich frakcji. Nie prowadzono tego rodzaju badań dla lekkich materiałów wypełniających. Omówione w niniejszej publikacji badania oraz uzyskane wyniki pozwalają stwierdzić, że powyższe doświadczenia mogą być bardzo pomocne przy doborze jakościowym danego materiału obniżającego gęstość projektowanego zaczynu cementowego. W podobny sposób badaniom można poddać środki przeciwdziałające frakcjonowaniu wypełniaczy lekkich.

Spośród badanych materiałów wypełniających stosowanych w technologii zaczynów uszczelniających mikrosfery glinokrzemianowe typu GK oraz mikrosfery CK ulegały mocnemu frakcjonowaniu w wodzie, co może mieć przełożenie na brak wymaganej stabilności sedymentacyjnej zaczynu lekkiego z dodatkiem tego rodzaju mikrosfer. Zaobserwowano również bardzo mocne frakcjonowanie perlitu PF. Jednym ze środków zaradczych w celu uzyskania wymaganej stabilności sedymentacyjnej zaczynu cementowego jest użycie najmniej frakcjonującej mikrosfery HG5K, będącej mikrosferą szklaną o znacznie większej powierzchni właściwej.

Artykuł powstał na podstawie prac badawczych pt.: Analiza możliwości poprawy stabilności sedymentacyjnej zaczynów cementowych - praca INiG - PIB na zlecenie MNiSW; nr zlecenia: 0036/ KW/2016, nr archiwalny: DK-4100/0036/2016 oraz Analiza możliwości doszczelnienia mikrostruktury płaszcza cementowego za pomoca nowych domieszek drobnoziarnistych - praca INiG - PIB na zlecenie MNiSW; nr zlecenia: 0044/KW/2019, nr archiwalny: DK-4100/0034/2019.

\section{Literatura}

Jordan A., Pernites R., Albrighton L., 2018. Low-density, lightweight cement tested as alternative to reduce lost circulation, achieve desired top of cement in long horizontal wells. Drilling Contractor, September/October: 62-64.

Kremieniewski M., 2017a. Poprawa stabilności sedymentacyjnej zaczynu cementowego, Nafta-Gaz, 4: 242-249. DOI: 10.18668/ NG.2017.04.04.

Kremieniewski M., 2017b. Wpływ perlitu pylistego na własności technologiczne zaczynu cementowego. Nafta-Gaz, 12: 943-952. DOI: 10.18668/NG.2017.12.05.

Kremieniewski M., 2018. Poprawa wczesnej wytrzymałości mechanicznej płaszcza cementowego powstałego z zaczynu lekkiego. Nafta-Gaz, 8: 599-605. DOI: 10.18668/NG.2018.08.06.

Kremieniewski M., 2019a. Korelacja wyników badań filtracji i wczesnej wytrzymałości mechanicznej zaczynów cementowych z dodatkiem mączki krzemionkowej. Nafta-Gaz, 7: 394-403. DOI: 10.18668/ NG.2019.07.03.

Kremieniewski M., 2019b. O konieczności prowadzenia serwisowych badań parametrów technologicznych zaczynów uszczelniających. Nafta-Gaz, 1: 48-55. DOI: 10.18668/NG.2019.01.07.

Kremieniewski M., 2019c. Receptury zaczynów do uszczelniania kolumn rur posadowionych w otworach wierconych w skałach chłonnych. Nafta-Gaz, 8; 451-457. DOI: 10.18668/NG.2019.08.01.

Kremieniewski M., Stryczek S., 2019. Zastosowanie cementu wysokoglinowego do sporządzania zaczynów uszczelniających w technologiach wiertniczych. Cement Wapno Beton, 3: 215-226.

Kremieniewski M., Stryczek S., Wiśniowski R., Rzepka M., Gonet A., 2017. Wpływ dodatku montmorylonitu /bentonitu/ na parametry świeżego i stwardniałego zaczynu cementowego. AGH Drilling, Oil, Gas, 34: 323-334.

Nelson E.B. et al., 1990. Well Cementing. Schlumberger Educational Service, Houston, Texas, USA.

Peng Ya, Jacobsen S., 2013. Influence of water/cement ratio, admixtures and filler on sedimentation and bleeding of cement paste. Cement and Concrete Research, 54: 133-142. DOI: 10.1016/j. cemconres.2013.09.003.

Stryczek S., Gonet A., Wiśniowski R., 2005. Wpływ wybranego dodatku mineralnego na własności technologiczne zaczynów cementowych. Wiertnictwo, Nafta, Gaz, 22/1: 333-341.

Stryczek S., Wiśniowski R., Gonet A., Ferens W., 2009. Parametry reologiczne świeżych zaczynów uszczelniających w zależności od czasu ich sporządzania. Wiertnictwo, Nafta, Gaz, 26/1-2: 369-382.

Stryczek S., Wiśniowski R., Gonet A., Złotkowski A., 2014. The influence of time of rheological parameters of fresh cement slurries. $A G H$ Drilling, Oil, Gas, 31: 123-133. DOI 10.7494/drill.2014.31.1.123.

Wiśniowski R., Stryczek S., Skrzypaszek K., 2007. Kierunki rozwoju badań nad reologią płynów wiertniczych. Wiertnictwo, Nafta, Gaz, 24: 595-607.

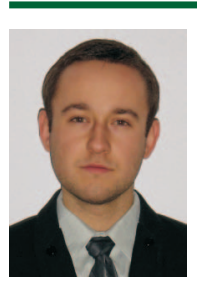

Dr inż. Marcin KREMIENIEWSKI

Adiunkt w Zakładzie Technologii Wiercenia Instytut Nafty i Gazu - Państwowy Instytut Badawczy ul. Lubicz $25 \mathrm{~A}$

31-503 Kraków

E-mail: marcin.kremieniewski@inig.pl

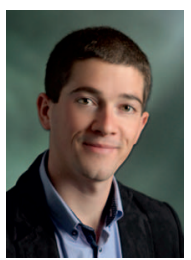

Mgr inż. Miłosz KĘDZIERSKI

Specjalista inżynieryjno-techniczny w Zakładzie

Technologii Wiercenia

Instytut Nafty i Gazu - Państwowy Instytut Badawczy

ul. Lubicz 25 A

31-503 Kraków

E-mail: milosz.kedzierski@inig.pl 